\title{
PRIVÁTNE ZNAČKY
}

\author{
Eva Poliačiková
}

Kl’účové slová:

privátna značka, obchodná značka, lojalita, stratégie zavádzania, zákazník

\section{Key words:}

privat mark, trade mark, loyality, strategy of introduction, customer

\begin{abstract}
Abstrakt:
Tento príspevok vznikol s úmyslom umožnit' čitatel'ovi zorientovat' sa v nových pojmoch, postupoch, ktoré so sebou prináša zavádzanie privátnych značiek. Obsahuje definovanie pojmu privátnej značky, jej postupné etablovanie na trhu, význam privátnych značiek pre výrobcov, predajcov i spotrebitel'ov. Ďalej poskytuje členenie privátnych značiek, ako i stratégie ich zavádzania. Posledná čast' príspevku pojednáva o vzt’ahu zákazníka a značky, funkciách značky a typoch zákazníkov, delených podl’a lojality zákazníkov ku značke.
\end{abstract}

\begin{abstract}
Abstact:
This paper has arison with the view of allow to readers to inform about the new intellectons, practices, taht are to be used by introduction of privat marks. Its includes definition of privat mark, its phased implant on the market, importance of privat marks for producers, sellers and consumers. Further provides segmentation of privat marks as well as the strategy of theirs introduction. Final phase of this paper deals about relationship of the customer and mark, of the functions of marks and types of customers divided by loyality of customers to mark.
\end{abstract}

\section{Úvod:}

Na slovenskom maloobchodnom trhu sa pojem privátna značka začal používat' pred niečo viac ako desat'ročím. Postupne sa výrobky privátnych značiek začali dostávat' do povedomia zákazníkov a stávajú sa súčast’ou každodenných nákupov. Zavádzaniu privátnych značiek je v súčasnej dobe venovaná vel'ká pozornost'. S príchodom zahraničných maloobchodných ret'azcov súvisí aj ponuka výrobkov, ktorých obal je špecifický tým, že neobsahuje logo alebo názov výrobcu, ktorý ho vyrobil, ale meno predajcu, prípadne názov, ktorý danému výrobku dal predajca.

S privátnymi značkami sa v slovenskom maloobchode stretávame pomerne krátke obdobie, preto zdroje o nich vychádzajú hlavne $\mathrm{z}$ anglickej písanej literatúry, ktorá nám poskytla množstvo dôležitých a zaujímavých informácií. Slovenská literatúra nám v súčasnej dobe poskytuje len obmedzené množstvo zdrojov. V tomto zmysle sú poskytnuté informácie, týkajúce sa témy vlastných značiek, čerpané hlavne z článkov v odborných časopisoch.

\section{Definície privátnej značky}

Často tiež nazývané obchodné značky sú najvýznamnejšou formou vlastných značiek. Výrobky, ktoré sú nositel'mi názvu maloobchodníka, napríklad Tesco pomarančový džús alebo Sainsbury limonáda, nazývame výrobkami privátnych značiek. Podobne ako pri druhových značkách, je ich balenie vel'mi dôležité ako prostriedok komunikácie kvality výrobku a imidžu obchodu. V porovnaní s druhovými značkami je obal výrobkov privátnych 
značiek viac sofistikovanejší a často navrhnutý tak, aby priamo konkuroval lídrovi v danej tovarovej kategórii (Isaac, B., 2000, str. 106).

Nôtová (2005) definuje privátnu značku ako maloobchodnú značku, vlastnenú a predávanú maloobchodníkom. Podl'a nej tiež privátnu značku tvoria všetky produkty, ktoré sú vyrábané pre určitého maloobchodníka za účelom predaja v jeho obchode a znamená predovšetkým:

- $\quad$ zvýšenie lojálnosti zákazníka,

- $\quad$ rozšírenie ponuky výberu,

- $\quad$ uspokojenie potrieb zákazníka,

- $\quad$ zvýšenie ziskovosti,

- podporu výroby.

Z pohl'adu zákazníka privátna značka ul'ahčuje orientáciu spotrebitel'a v množstve značiek na trhu, šetrí čas a energiu a tým má verný zákazník má skrátený rozhodovací proces a vytvára pocit intimity a familiarity pri nákupe.

Z pohl'adu výrobcu zaručuje stálost' a hromadnost' predaja a výroby, dlhodobú spoluprácu a znižuje výrobné náklady (Nôtová, I., 2005).

Druhové značky sa postupne hlavne v USA začali menit' na privátne značky a to tým, že ich predajca si na ich obal doplnil svoje meno alebo logo. Tieto privátne značky sa stali tzv. napodobneninami, ktoré imitovali vedúcu výrobnú značku vo svojej kategórii.Imitácie sa týkali obalu výrobku, použitých farieb a písma. V predajniach boli tieto napodobneniny vystavené takmer vždy vedl'a tradičných výrobných značiek. Okrem toho chceli predajcovia zaistit' dostatočnú kvalitu svojich privátnych značiek preto začali podrobnejšie skúmat' výrobné značky, ktoré boli významné vo svojej kategórii. Tento proces sa nazýval spätné riadenie (Reverse engineering). Možno povedat', že doslova parazitovali na výrobcovi, jeho inováciách, výskume, vývoji a imidži výrobkov. Tým sa zvyšovali aj náklady predajcu na výskum, marketing a predaj výrobkov pod vlastnou značkou. Následkom toho bolo hl'adanie dodávatel'ov, ktorí by im vyrobili požadované výrobku za čo najnižšie ceny. Výhodou taktiež bolo, že napodobneniny nečelili takému riziku, ako výrobné značky pri zavádzaní nových výrobkov. Výsledkom je, že predajcovia si zaknihovali vyššie zisky spôsobené vyššími výnosmi z predaja vlastných značiek (Kumar, N; 2007, s. 13, 27).

Privátne značky sú na trhu už pomerne dlhý čas. Avšak napriek vysokým očakávaniam, privátne značky boli v začiatkoch považované za „chudobnejšieho brata“ značkových výrobkov a dosahovali vel'mi nízke podiely predajnosti, preto sa nepredpokladalo, že sa stanú významnejšími (Thomassen, L., 2008, s. 16).

Značky nám dávajú zmysel ked’ sme v roli zákazníka. Spotrebitelia požadujú značky z dôvodu zabezpečenia si kvality a emocionálnej spokojnosti. Produkt, ktorý nemá značku, bude mat' sám o sebe nedostatočnú prít'ažlivost'. Výrobok nepotrebuje byt' nevyhnutne pod značkou svojho výrobcu - je tu aj d'alšia možnost' a to byt' pod značkou jeho predajcu. A to je to, čo je možné vidiet' už niekol'ko rokov (Lincoln, K, 2008, s. 18).

V súčasnosti môžeme privátne značky vidiet' na 95 percentách kategórií spotrebitel'ských balení tovarov. Takisto maloobchodníci zavádzajú privátne značky aj pri takých kategóriách, pri ktorých je spotrebitel' verný tradičným značkovým výrobkom. V posledných rokoch najrýchlejšie rastúcimi kategóriami privátnych značiek sú rúže, zvlhčovače pokožky a detské potraviny (Kumar, N., 2007, s. 28, 39). 
Všeobecne možno povedat', že tri najlepšie predávané privátne značky v tovarovej kategórii food sú mlieko, vajcia a chlieb a sáčky na odpad, poháre a taniere a toaletný papier v tovarovej kategórii non-food (Steenkamp, J.B., 2007, s. 28).

S postupnou inváziou privátnych značiek si začali jednotliví predajcovia uvedomovat', že klasická privátna značka im pomáha v konkurencii s tradičnými výrobnými značkami, ale určite im nepomáha diferencovat' obchod od ostatných predajcov. Zákazník nemal dôvod nakupovat' určitú privátnu značku u určitého predajcu, ked’že všetci predajcovia mali rovnakú privátnu značku a jediné, čo ich odlišovalo od ostatných bolo meno na etikete.

\section{Postupné zlepšovanie}

Privátne značky tradične boli u zákazníkov známe svojimi bielymi baleniami s čiernymi nápismi, ktoré spotrebitelia mohli nájst' niekde na spodnom regály v predajni a ktoré boli lacným a neprítažlivým substitútom za značkový výrobok. Ale časy sa menia. Zmeny v privátnych značkách sa nestali bez povšimnutia zákazníkov. Zlepšenia z nich urobili akceptovatel’nú alternatívu nákupu pre širokú skupinu zákazníkov (Kumar, N., 2007, str. 4). V zhode s pozitívnym vnímaním, spotrebitelia stále viac hl'adajú v predajniach výrobky privátnej značky. V minulosti boli privátne značky primárne zamerané na skupinu zákazníkov s nižšou kúpyschopnost'ou (Kapferer, J. N., 2004, s. 23). Kým dnes spotrebitelia s nižšími príjmami nakupujú častejšie výrobky privátnych značiek ako ostatní, možno pozorovat', že aj solventnejší zákazníci siahajú po privátnych značkách. Je to spôsobené uvedomením si, že radšej kúpime za nižšiu cenu výrobok porovnatel'nej kvality, ako by sme dali prednost' výrobcovi drahého značkového výrobku. V Nemecku tomu hovoria "stinginess is brill" lakomstvo je fajn. Výsledkom je skutočnost', že privátne značky sa stali akceptované širokou skupinou zákazníkov, ktorí sa pre ne rozhodujú ovel'a l'ahšie (Steenkamp, J. B., 2007, str.12).

Niekedy v sedemdesiatych rokoch sa veci začali menit', aj ked' pomaly, ale maloobchodníci začali rozvíjat' svoju predajnú siet'. Niektorí, napríklad Ahold, Carrefour alebo Metro, dokonca prekročili svoje teritoriálne hranice a začali expandovat'. Rozširovanie maloobchodníkov zmenilo rovnováhu síl medzi nimi a výrobcami značiek. Predajcovia sa v súčasnosti zmocnili sily, ktorá pre nich znamená výhodu pri vyjednávaní. Výrobcovia značkových výrobkov boli preto prekvapení z neočakávaných nárastov predaja privátnych značiek od sedemdesiatych rokov. Jasným príkladom môže byt' Nemecko, najväčšia európska ekonomika a tretia najväčšia ekonomika sveta. Podiel privátnych značiek sa zvýšil za posledné tri dekády z $12 \%$ na takmer 34\% (Kumar, N., 2007, str. 4). Hoci podiely privátnych značiek na celkových tržbách rastú vo všetkých rozvinutých ekonomikách, v posledných rokoch ich rast nemôžeme považovat' za lineárny. Často sa špekulovalo, že nakupovanie výrobkov privátnych značiek je niečo čo sa objavuje v recesii.

\section{Od lojality značkových výrobkov k lojalite privátnych značiek}

Rastúca akceptovatel'nost' privátnych značiek vedie k znižovaniu lojality dobre známych značkových výrobkov. To malo za následok, niektorým značkám rapídne klesol ich podiel na trhu z dôvodu "kanibalizácie" privátnych značiek. Rast privátnych značiek a s tým aj sily maloobchodných ret’azcov vedie významných výrobcov značiek k zmene ich stratégie. Začína dochádzat' k rôznym konfliktom medzi výrobcom a maloobchodníkom ako spotrebitel'om a maloobchodníkom ako konkurentom. Maloobchodníci sú náchylnejší vyčlenit' najlepšie miesto v regály práve pre svoje vlastné značky, kým výrobca s tým jasne nesúhlasí. Maloobchodníci majú pocit, že ich výhoda je vo vel'kom cenovom rozdiele medzi ich privátnom značkou a značkovým výrobkom. Obidve zúčastnené strany participujú na 
inováciách produktov, ale predajcovia často chcú tieto zlepšenia len čím skôr skopírovat' (Steenkamp, J. B., 2007, s. 5).

Príkladom môže byt' prípad v Anglicku, kde výrobok maloobchodného ret'azca J. Sainsbury skoro presne skopíroval písmená a farbu výrobku Classic Coke a výsledkom bolo, že po šiestich mesiacov od uvedenia dosiahol $17 \%$-ný podiel na trhu kolových nápojov. Predajcovia by chceli zapojit' výrobcov do výroby privátnych značiek a tak získat' podiel na ich najnovších výrobných technológiách, avšak mnohí to odmietajú a vyhlasujú, že nikdy nepodstúpia takým praktikám (Kumar, N., 2007, str. 4).

\section{Príležitosti pre výrobcov a predajcov}

V súčasnosti sa vel'a hovorí o raste maloobchodných značiek alebo privátnych značiek. Ponúkajú schopnost' prežit' tak predajcom, ktorí svojou ponukou privátnych značiek získajú lojalitu svojich zákazníkov, ako aj výrobcom ak nemajú naplnené výrobné kapacity. Rovnako nemenej dôležitou skutočnost'ou sú príležitosti, ktoré privátne značka prináša. Príležitost'ou pre predajcov je zdokonal'ovanie ponuky výrobkov. Pre výrobcov môže byt' príležitost'ou optimalizovat' výrobnú kapacitu a príležitost’ou pre nás všetkých ako spotrebitel'ov stále širšia a lepšia ponuka výrobkov (Floor, K., 2006, s. 160).

\section{Privátna značka bez mena maloobchodníka}

Najlepším príkladom tejto značky je vlastná značka St. Michael, ktorú zaviedol maloobchodný ret'azec Marks\&Spencer, Clever od Billy alebo Albert od Aholdu. Tieto značky sú predávané len v sieti daného maloobchodníka. Spotrebitelia, ktorí nie sú oboznámení s vlastnými značkami nemusia tieto privátne značky rozpoznat' a často ani nevedia, že ich nakupujú. Jedným dôležitým rozdielom medzi privátnou značkou s menom a bez mena maloobchodníka je v tom, že výrobok s menom maloobchodníka konkuruje tradičným značkám spoliehajúc sa na imidž a reputáciu, kým výrobok bez jeho mena sa musí zaobíst' bez tejto podpory. Privátne značky, ktoré nie sú nositel'mi mena maloobchodníka nemajú tendenciu sa podobat' ich značkovým konkurentom, preto unikajú kritike vlastníkov značiek (Isaac, B., 2000, str. 107).

\section{Druhy privátnych značiek}

Prémiové/exkluzívne značky

Prémiové privátne značky majú v porovnaní s klasickými napodobneninami vyššiu cenu, ale aj lepšiu kvalitu, zatial' čo v porovnaní s vedúcimi výrobnými značkami vo svojej kategórii je cena síce nižšie, ale kvalita zostáva stále lepšia. Dôležitým rozdielom medzi prémiovými privátnymi značkami a klasickými privátnymi značkami jasná vízia predajcu odlíšit' sa od výrobných značiek spojená s absenciou pokusu o kopírovanie obalov významných výrobných značiek. Prémiové privátne značky tak pomáhajú spotrebitel'om získat' obdiv od ostatných. Tieto privátne značky sú znakom bohatstva. Bez vy̌šsej ceny by mohla stratit' značka svoju prít'ažlivost'. Preto možno hovorit' o pozitívnej cenovej elasticite - čím je cena vyššia tým je vyššia aj prít’ažlivost' výrobku. (Isaac, B., 2000, str. 106).

Stále viac spotrebitel'ov vynakladá viac peňažných prostriedkov na luxusnejšie výrobky. Situácia je dôsledkom zvyšujúcej sa prosperity a životnej úrovne. Dokonca aj spotrebitelia s nižšími príjmami kupujú drahšie značkové výrobky. To vyvracia teda fakt, že pozicioning výrobkov nie je len o nízkych cenách. Spotrebitelia nakupujú tieto výrobky, lebo u nich indikujú lepšiu kvalitu v porovnaní s lacnejšími výrobkami. Avšak nie je to len vyššia cena, pre ktorú výrobok kupujú. Niektorí kupujúci sa tým chcú odlíšit’ od ostatných. 


\section{"Premium-lite"}

"Premium-lite" sú také privátne značky, ktoré nesú jasný odkaz - "lepšie a lacnejšie“. Na trhu sa pokúšajú presadit' svojou rovnakou alebo lepšou kvalitou ako majú vedúce výrobné značky ale nižšou cenou.

\section{"Premium-price"}

"Premium-price" na druhej strane sú také privátne značky, ktoré majú aj vyššiu cenu aj výnimočnú kvalitu v porovnaní s výrobnými značkami. Snažia sa byt' tým najlepším, čo môže zákazník za danú cenu kúpit’.

Kým prémiové privátne značky typu "Premium-price" svojich zákazníkov stále hl'adajú, značky typu "Premium-lite" sa stali v posledných rokoch vel'mi populárne. V súčasnosti je trend prémiových značiek považovaný za jeden z najvýznamnejších v maloobchode (McKinley, I., 2004, s.77).

Podobne ako ich značkový konkurenti aj prémiové značky sú nositel’mi prémiovej ceny a vo väčšine prípadov majú aj charakteristické meno a balenie. Preto sú to hlavne prémiové značky, ktoré si za svoj zovňajšok vysluhujú množstvo kritiky od výrobcov tradičných značiek (Isaac, B., 2000, str. 107).

\section{Stratégie zavádzania privátnych značiek}

Stratégia "Kvázi" značky

Skupinu "Kvázi” značiek reprezentujú značky diskontných ret’azcov. Výrobky majú síce určitú značku, ale tou nie je vlastné meno maloobchodníka. Spotrebitelia tak nie sú pri nákupe týchto výrobkov oboznámení s menom obchodu a preto nerozlíšia tento výrobok, ako výrobok vlastnej značky. Jedným zo základných rozdielov je, že výrobky s menom obchodu sú nositel'mi imidžu a dobrého mena obchodu zatial' čo Kvázi značky musia obstát' na trhu bez takejto podpory. Výhodou pre ne môže byt' snád' to, že l'ahšie uniknú kritike spotrebitel'ov. Stratégia "Kvázi" značky používa obvykle viac ako 50 rôznych vymyslených značiek na výrobkoch privátnych značiek.

Silnou stránkou týchto privátnych značiek je, že:

- vytvárajú dojem širokého sortimentu výrobkov,

- $\quad$ svojou ponukou nahradzujú sekundárne a terciárne značky,

- spotrebitel' si nespája nedostatky a chyby týchto výrobkov s menom maloobchodníka.

Nevýhodou pre ne môže byt':

- $\quad$ pomerom nízkej ceny a nízkej kvality si t’ažšie budujú lojalitu u spotrebitel’ov,

- $\quad$ spotrebitelia si nespájajú značku výrobku s menom maloobchodníka,

- $\quad$ musia mat’ najnižšiu cenu vo svojej kategórii (Cariolis Research, 2002).

\section{Stratégia obchodnej značky}

Sú dôležitou podstatou výrobkov vlastných značiek. Podobne ako pri druhových značkách, aj pri obchodných je ich balenie vel'mi dôležité ako prostriedok komunikácie kvality výrobku a imidžu obchodu. Avšak na porovnanie s druhovými značkami je vzhl'ad balení výrobkov obchodných značiek viac sofistikovaný a často navrhnutý tak, aby mohol konkurovat' 
značkovým lídrom v daných kategóriách. Stratégia obchodných značiek sa vyznačuje používaním jednotnej značky na všetkých výrobkoch privátnych značiek. Stratégiu využíva väčšina maloobchodných ret’azcov.

Stratégia obchodných značiek sa rozdel'uje na 2 základné druhy.

Obchodná značka: Pri tejto stratégii všetky výrobky privátnych značiek nesú meno maloobchodníka.

Výhody:

- l'ahká identifikácia výrobkov,

- jasné posolstvo značky,

- $\quad$ spojenie privátnej značky s obchodom

Nevýhody:

- možnost' zvyšovanie predaja aj pri zvýšení ceny

- nedostatky výrobkov si spotrebitel' asociuje s menom maloobchodník,

- vyžadujú investície do výskumu, vývoja, manažmentu a reklamy (Cariolis Research, 2002).

Skupinová značka: Pri ktorej výrobky všetkých privátnych značiek nesú určité pomenovanie, ktorým nie je meno maloobchodníka. Na Slovensku túto stratégiu preferujú maloobchodné ret’azce Billa s výrobkami Clever a Ahold a výrobkami Albert.

Výhody:

- značka môže byt' používaná v rôznych predajniach v rámci skupiny,

- vytvorenie skupinovej identity,

Nevýhody:

- menšia asociácia produktu s menom maloobchodníka.

- značka nie je priamo spojená s menom maloobchodníka,

- vyžadujú investície do výskumu, vývoja, manažmentu a reklamy (Cariolis Research, 2002).

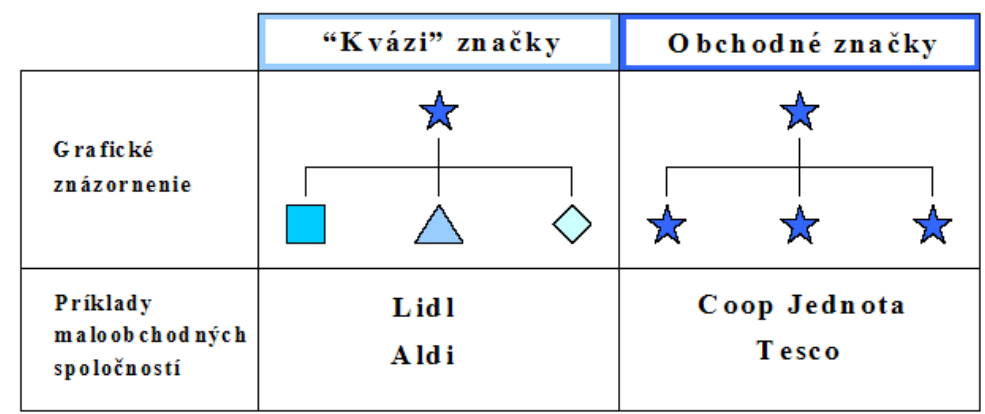

Schéma 1: Základné typy stratégií privátnych značiek

Prameň: Cariolis Research, 2002

\section{Zákazník a značka}

Značka reprezentuje všetko, čo človek vie o výrobku ako nositel'ovi značky a čo pre neho daný výrobok znamená. Je to súhrn jeho pocitov, vedomostí a skúseností so značkou. To znamená, že spotrebitel' nemusí strávit’ čas výskumom produktu vždy ked' sa ho rozhodne 
kúpit'. Spotrebitel'ské hodnotenie produktu je založené na jeho okamžitom rozpoznaní na základe jeho značky (Aaker, A. D., 1991, s. 16).

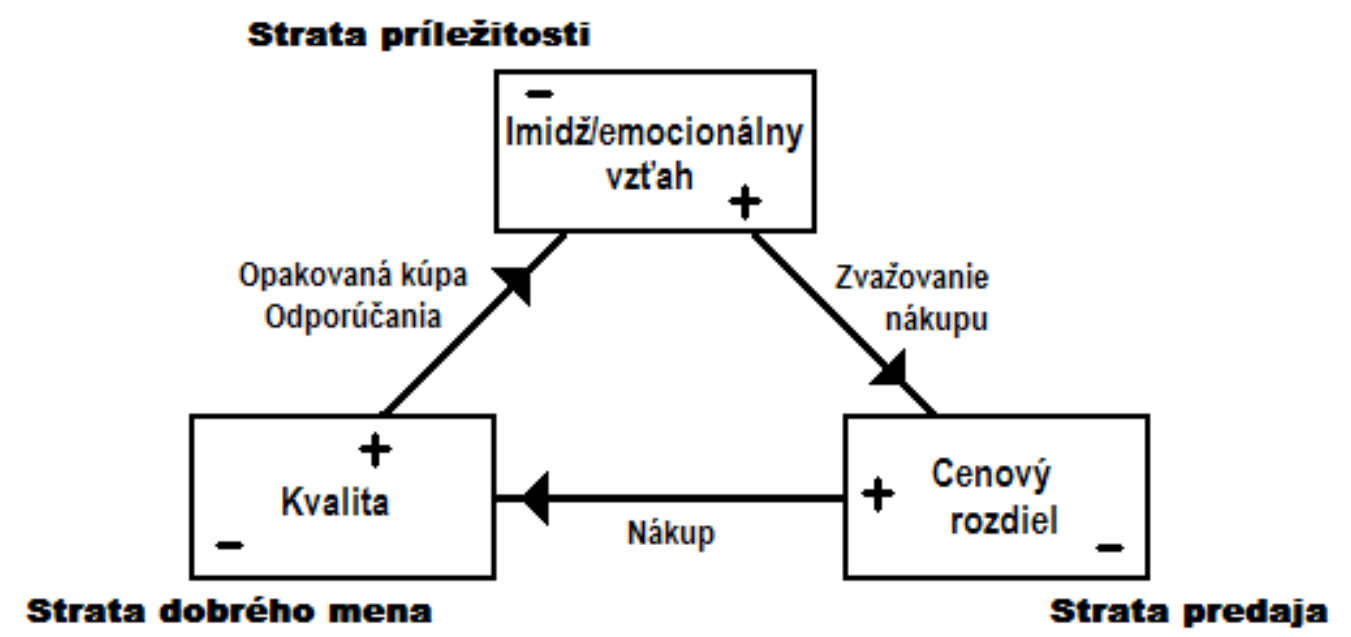

Schéma 2: Rozhodnutia zákazníka

Prameň: Kumar, N., 2007, s. 196

Rozhodnutie, či zákazník daný značkový produkt kúpi resp. nekúpi, možno rozdelit' na niekol'ko fáz. Schéma 2 nám zobrazuje ako spotrebitelia uplatňujú informácie o imidži, cene a kvalite výrobkov pri svojich nákupných rozhodnutiach.

Ak značka nemá dobrý imidž, šanca, že spotrebitel’ ju kúpi, je mizivá. Naopak, ak značka zaujme zákazníka prihliada sa na cenovú konkurencieschopnost' značiek. Ak je cenový rozdiel medzi výrobnou značkou a privátnou značkou akceptovatel’ný, zákazník kúpi výrobok privátnej značky a nasleduje overenie kvality výrobku zákazníkom. Tým, že zákazník výrobok spotrebuje alebo použije, dostane odpoved' na otázku, či daný výrobok splnil jeho očakávania a či je dostatočne spokojný, aby si vytvoril s privátnou značkou vzt’ah (Kumar, N., 2007, s. 196)

Pri budovaní a získaní hodnotného prínosu pre značku je potrebné upriamit' pohl'ad na tri pravidlá: riadenie ceny s ciel'om byt' konkurencieschopný, neustále zlepšovanie kvality a vytváranie citovej väzby a pevného vzt'ahu so zákazníkom. Jednou z najdôležitejších otázok pri riadení výrobných a maloobchodných značiek je cenová konkurencieschopnost' produktu. Ak cena tradičnej značky je v porovnaní s privátnou značkou maloobchodníka vyššia, objem jej predaja klesá. Na druhej strane je l'ahké znižovat' ceny, ale vel'mi nízke ceny môžu mat' v konečnom súčte neprimeraný dopad. Preto pred úpravou ceny je dôležité pochopit' cenovú elasticitu, čo znamená pochopit', čo sa stane, ak meníme cenu výrobku a krížovú elasticitu, ktorá nám ukáže, ako sa zmení množstvo predaných výrokov, to znamená rozdiel medzi nami a konkurenciou. Výsledkom zvyšovania cenového rozdielu medzi značkovými výrobkami a výrobkami privátnych značiek sú často zlyhania vo vývoji nových produktov a strata vedúcich pozícií $\mathrm{v}$ tovarových kategóriách. Ak cena výrobkov už zákazníkov neoslovuje $\mathrm{v}$ dostatočnej miere, začínajú značky bojovat' o ich povedomie rôznymi formami podpory predaja. Tie môžu zahrňovat' kupóny na nákup, dočasné zníženia cien, výrobky zadarmo, darčeky alebo dva výrobky za cenu jedného. Tým sa očakáva, že časom sa určité percento týchto zákazníkov stane lojálnymi používatel'mi značky (Kumar, N., 2007, s.196). 


\section{Funkcie značky z pohl’adu zákazníka}

Značka napíňa rôzne funkcie pre zákazníka. Bez ohl'adu či sú zákazníci nevšímaví alebo naopak všetko prepočítavajúci a vždy v strehu, hrá značka dôležitú rolu. Dôležitost' značky vychádza z nasledujúcich funkcií:

- Identifikácia - jasná viditel’nost', pochopenie zmyslu ponuky, rýchla spoznanie hl'adaného výrobku.

- Praktickost' - umožnit' šetrit' čas a energie prostredníctvom lojality a uskutočnením opakovaného nákupu.

- Garancia - istota nemennej kvality značkového výrobku, bez ohl'adu na to, kde a kedy spotrebitel' tento výrobok kúpi.

- Optimalizácia - istota kúpy najlepšieho výrobku v jeho kategórii.

- Znak - potvrdenie vlastného imidžu, alebo imidžu, ktorý chce značka prezentovat' okoliu.

- Spojitost' - spokojnost', vytvorená vzt'ahom dôvery k značke, ktorú spotrebitel' už roky nakupuje.

- Pôžitok - očarenie spojené s atraktivitou značky, k jej logu, komunikácii a skúsenost’ami s ňou.

- Etickost' - spokojnost' spojená s dôveryhodným správaním značky vo vzt'ahu k spoločnosti (Walser, M. G., 2004, str. 12).

\section{Typy zákazníkov z pohl’adu lojality k značke}

\section{Lojálni zákazníci}

Každá značka má určité percento oddaných zákazníkov. Tými sú zákazníci, ktorí nakupujú daný výrobok pravidelne. Avšak vel'mi málo zákazníkov je absolútne lojálnych k určitej značke. Existujú aj takí "lojálni“" zákazníci, ktorí sa rozhodnú kúpit’ inú - alternatívnu značku a to z dôvodu, že ich preferovaná značka nie je v predajni k dispozícii alebo iná značka má pôsobivejšiu reklamu a lepšiu ponuku. Odhaduje sa, že týchto zákazníkov reprezentuje menej ako 20 percent zákazníkov, ktorí preferujú konkrétnu značku. Tento princíp je založený na Paretovom pravidle a títo zákazníci vygenerujú 80 percent objemu predaja značky (Gamble, P. R., 2007, s. 283, 284).

Rovnako vel'ké množstvo zákazníkov, ktorí majú svoju preferovanú značku, je stimulovaných ku kúpe alternatívnej značky, často následkom podpory predaja. Preto spoločnosti musia zamerat' propagáciu svojich výrobkov na tých zákazníkov, ktorí seba charakterizujú ako lojálnych $\mathrm{k}$ danej značke produktu, aby nedošlo k migrácii k iným konkurenčným značkám. Znamená to vytvorit’ značke takú podporu, ktorá posilní jej dôležité vlastnosti a poskytne zákazníkovi dôvod k opakovaným nákupom (Tapp, A., 2007, s. 283).

S iným pochopením u týchto zákazníkov sa môže stretnút' cenové zvýhodnenie výrobku danej značky. Kým u niektorých to vzbudí záujem kúpit' viac výrobkov ,u iných to môže mat' za následok zvyšovanie pochybností o značke alebo upriamenie zákazníka len na cenu, čím by s väčšou pravdepodobnost'ou mohol zvažovat' aj kúpu konkurenčných značiek. Všetky značky pôsobia na vel'mi silnom konkurenčnom prostredí, preto aktivity, založené na cenovej podpore, 
sú nevyhnutné na vytvorenie protipólu s konkurenciou s pokusom predíst', aby lojálni zákazníci odišli k inej značke (Yeshin, T., 2006, s. 80).

\section{Kmeňoví zákazníci}

Zahŕňajú zákazníkov, ktorí majú tendenciu nakupovat' obmedzený rozsah značiek v kategórii. Podobne, aj títo zákazníci reagujú na rôzne podpory predaja. Reprezentujú najväčšiu skupinu zákazníkov, ktorí si vyberajú výrobok podl'a vlastného zoznamu značiek, ktoré uspokojujú ich vlastné alebo rodinné potreby. V niektorých prípadoch odrážajú charakter príležitosti, kedy sa používajú. Určitá značka výrobku sa nakupuje ku každodennej spotrebe, zatial' čo iná iba pri príležitosti zábavy alebo pohostenia väčšej skupiny l'udí (Gamble, P. R., 2007, s. 283, 284).

Jasne možno povedat', že zo všetkých typov zákazníkov, má na kmeňových zákazníkov podpora predaja najväčší vplyv. Podpora nákupov u časti zákazníkov môže znamenat' výhodu pre značku rôznymi spôsobmi. V niektorých príkladoch, obzvlášt', ked' rastie spotreba obyvatel'stva, je dobré, ak má zákazník daný výrobok v domácnosti, pretože to väčšinou vedie k jeho častejšej spotrebe a tým aj ku kúpe. Politika podpory predaja ovplyvňuje schopnost' spoločnosti prilákat' a udržat' zákazníkov a to presvedčením, aby prešli práve na ich značku, aby ju kupovali častejšie a vo väčších množstvách (Yeshin, T., 2006, s. 81).

\section{Promiskuitní zákazníci}

Títo zákazníci vel’mi často menia značky na základe ich vnímania. To znamená, že kúpia tú značku, ktorá má najlepšiu ponuku v danom čase. Môžeme povedat', že hlavnými motivačnými faktormi sú pre danú skupinu zákazníkov cena a pridaná hodnota. Spotrebitelia, patriaci do tejto skupiny, sa často vyznačujú obmedzeným množstvom peňazí, preto si málokedy môžu dovolit’ kúpu drahších značiek. Na druhej strane vedia, že dostanú to najlepšie za danú cenu. Vo väčšine kategórií tvoria títo zákazníci malú skupinu, je tu však tendencia zvyšovania ich počtu (Yeshin, T., 2006, s. 81).

\section{Ignoranti značiek}

Poslednou skupinou sú zákazníci, ktorí nie sú „používatel’mi“ značiek. Dôvodom je rozmanitost' ich správania. Jedným z dôvodom môže byt' cena. Výrobok v určitej kategórii je vnímaný ako vel'mi drahý a teda neprináša dostatočnú hodnotu za danú cenu. Ďalším dôvodom je jeho nepotrebnost' alebo vnímanie jeho kúpy ako formu rizika. Týka sa to najmä tých zákazníkov, ktorí daný výrobok ešte nikdy nevyskúšali.

V tomto prípade je podpora predaja vel'mi dôležitá, aby sa vzbudila u potenciálnych zákazníkov dôvera aby výrobok kúpili a zmenili pohl'ad na značku (Yeshin, T., 2006, s. 37-38).

\section{Záver:}

Príspevok bol zameraný na oblast' privátnych značiek. Jeho úlohou bolo predovšetkým oboznámit' z východiskovými kategóriami, súvisiacimi s touto oblast'ou počnúc definovaním samotných pojmov privátnych značiek. Oboznamuje d’alej s ich členením, možnými stratégiami ich zavádzania do praxe. Druhá čast' príspevku nadväzuje na prvú čast'. Zaoberá sa vzt’ahom značiek a ich zákazníkov, funkciami značiek v tomto zmysle ako i členením zákazníkov podl’a preferencií značiek pri nákupoch. 


\section{Literatúra:}

[1] AAKER, A.D., 1991, Managing Brand Equity: Capitalizing on the Value of a Brand Name, Maxwell Macmillan International, 16 s. ISBN 13: 97-8002-9001-01-1.

[2] AAKER, A.D., KUMAR, N., STEENKAMP, J.-B., 2007, Private Label Strategy : How to Meet the Store Brand Challenge, Perseus Distribution Services, 13, 27, 28, 39 s. ISBN 13: 97-8142-21-0167-4.

[3] FLOOR, K., 2006, Branding a Store: How to Build Successful Retail Brand in a Changing Marketplace, Kogan Page, 160-161 s. ISBN 13: 97-8074-9448-32-5.

[4] GAMBLE, P.R., TAPP, A., MARSELLA, A., STONE, M., 2007, Marketing Revolution, Kogan Page, 283-284 s. ISBN: 97-8074-9449-80-3.

[5] HAIG, M., 2004, Brand Royalty, Kogan Page, 3 s. ISBN 13: 97-8074-94-4357-6.

[6] [6] ISAAC, B., 2000, Brand Protection Matters, Sweet \& Maawell, 25-27 s. ISBN 10: 042-1569-301.

[7] KAPFERER, J.-N., 2004, The new strategic brand management: Creating and sustaining brand equitz long term, Kogan Page, 12-25 s. ISBN 10: 074-9442-832

[8] LINCOLN, K., THOMASSEN, L., 2008, Private Label : Turning the Retail Brand Threat into Your Biggest Opportunity, Kogan Page, 1,2,15,16,20,21,34 s. ISBN 10: 074-9450-274.

[9] McKINLAY, I., O'CONNOR, M., ROSS, S., 2007, Marketing: Level 2, Pearson Education South Africa, 77 s., ISBN 13: 97-8186-89-1739-6.

[10] NÔTOVÁ, I., 2005, Privátne značky - strašiak či dobrodinec: Ret'azce sa snažia speňažit' silu vlastného mena a zlepšit' lojalitu zákazníkov. In: Trend. [online]. 22/11 2005. [cit:2009-11-2]. Dostupné na internete: <http://mediatrend.etrend.sk/reklama-amarketing/privatne-znacky-strasiak-ci-dobrodinec/58668.html>.

[11] WALSER, M.G., 2004, Brand Strength: Building and Testing Models Based on Experimental Information, DUV, 56, 57 s. ISBN-10: 3824479591, ISBN 13: 97-83824479-59-7.

[12] WILSON, J.S., BLUMENTHAL, I., 2008, Managing Brand You: Seven Step to Creating Your most Successful Self, Amacom, 171, 180 s. ISBN 13: 97-8081-44-1068-4.

[13] YESHIN, T., 2006, Sales Promotion, Cengage Learning EMEA, s. 80-83, ISBN 13: 978184-4801-61-9.

[14] MINÁROVÁ, M. 2009. Strategické marketingové analýzy. In. Vysokoškolská učebnica 2.kap. Strategický marketing. SPU:Nitra, 2009, s.27-59, ISBN 978-80-8070-966-2.

\section{Klasifikácia JEL: M 31}

\section{Ing. Eva Poliačiková, PhD.}

Odborná asistentka na katedre ekonomiky a manažmentu podniku

Ekonomická fakulta

Univerzita Mateja Bela

Banská Bystrica, SR

eva.poliacikova@umb.sk 